\title{
SUSTAINABLE DEVELOPMENT GOALS (SDGs) \\ DAN PENGENTASAN KEMISKINAN
}

\author{
OLEH: \\ ISHARTONO $^{1} \&$ SANTOSO TRI RAHARJO $^{2}$ \\ 1 Mahasiswa Program Studi Kesejahteraan Sosial Pasca Sarjana-Universitas Padjadjaran \\ 2 Staf Pengajar Pada Departemen Kesejahteraan Sosial—Universitas Padjadjaran \\ (ishartono@unpad.ac.id; santoso.tri.raharjo@unpad.ac.id)
}

\begin{abstract}
ABSTRAK
Isu kemiskinan tetap menjadi isu penting bagi negara-negara berkembang, demikian pula dengan Indonesia. Penanganan persoalan kemiskinan harus dimengerti dan dipahami sebagai persoalan dunia, sehingga harus ditangani dalam konteks global pula. Sehingga setiap program penanganan kemiskinan harus dipahami secara menyeluruh dan saling interdependen dengan beberapa program kegiatan lainnya. Dalam SDGs dinyatakan no poverty (tanpa kemiskinan) sebagai poin pertama prioritas. Hal ini berarti dunia bersepakat untuk meniadakan kemiskinan dalam bentuk apapun di seluruh penjuru dunia, tidak terkecuali Indonesia. Pengentasan kemiskinan akan sangat terkait dengan tujuan global lainnya, yaitu lainnya, dunia tanpa kelaparan, kesehatan yang baik dan kesejahteraan, pendidikan berkualitas, kesetaraan jender, air bersih dan sanitasi, energy bersih dan terjangkau; dan seterusnya hingga pentingnya kemitraan untuk mencapai tujuan-tujuan tersebut.
\end{abstract}

\section{PENDAHULUAN}

Sampai dengan akhir abad 20 kemiskinan masih menjadi beban dunia. Nampaknya isu kemiskinan akan terus menjadi persoalan yang tidak akan pernah hilang di dunia ini. Dunia meresponnya dengan menyepakati suatu pertemuan pada September 2000 yang diikuti oleh 189 negara dengan mengeluarkan deklarasi yang dikenal dengan The Millenium Development Goals (MDG's). Salah satu targetnya adalah mengurangi jumlah penduduk miskin hingga 50\% pada tahun 2015. Deklarasi ini memberikan indikasi bahwa masalah kemiskinan masih menjadi masalah besar dunia yang harus ditanggulangi bersama.

Dengan berakhirnya era MDGs yang berhasil mengurangi penduduk miskin dunia hampir setengahnya. Selanjutnya saat ini memasuki era SDGs (sustainable development goals), yang dimulai dengan pertemuan yang dilaksanakan pada tanggal 25-27 September 2015 di markas besar PBB (Perserikatan Bangsa-Bangsa), New York, Amerika Serikat. Acara tersebut merupakan kegiatan seremoni pengesahan dokumen SDGs (Sustainable Development Goals) yang dihadiri perwakilan dari 193 negara. Seremoni ini merupakan lanjutan dari kesepakatan dokumen SDGs 
yang terjadi pada tanggal 2 Agustus 2015 yang juga berlokasi di New York. Saat itu sebanyak 193 negara anggota PBB mengadopsi secara aklamasi dokumen berjudul "Transforming Our World: The 2030 Agenda for Sustainable Development" atau "Mengalihrupakan Dunia Kita: Agenda Tahun 2030 untuk Pembangunan Berkelanjutan". Dokumen SDGs pun dicetuskan untuk meneruskan dan memantapkan capaian-capaian MDGs sebelumnya agar langgeng dan berlanjut seterusnya.

\section{Kemiskinan}

Bagi Indonesia sendiri, kemiskinan masih merupakan persoalan yang menjadi beban berat, terutama dikaitkan dengan isui kesenjangan yang semakin melebar antara si kaya dan si miskin. Sebagai bagian dari anggota PBB Indonesia tentunya berkomitmen untuk mengatasi persoalan seiring dengan deklarasi SDGs. Itu artinya Indonesia juga dituntut untuk mewujudkan target-target yang ditetapkan dalam deklarasi PBB tersebut. Upaya pemerintah untuk mengatasi kemiskinan secara integratif sebetulnya sudah dilakukan sejak tahun 1995, yaitu dengan dikeluarkannya Inpres Desa Tertinggal. Pemerintah melalui Peraturan Presiden Republik Indonesia nomor 15 tahun 2010 tentang Percepatan Penanggulangan

\footnotetext{
${ }^{1}$ http://www.bappenas.go.id/id/berita-dan-siaranpers/sektor-infrastruktur-prioritas-penggunaan-danadesa-2016/
}

Kemiskinan telah membentuk Tim Nasional Percepatan Penanggulangan Kemiskinan (TNP2K). Tim ini diketuai langsung oleh Wakil Presiden. Upaya nasional ini menunjukkan bahwa kemiskinan masih menjadi masalah yang serius. Bahkan pemerintah pusat telah merealisasikan penyaluran dana desa tahap pertama kepada pemerintah desa, sekitar 47 triliyun. Dana desa tersebut telah disalurkan oleh Kementerian Keuangan (Kemenkeu). Setelah disalurkan, Kementerian Desa, Pembangunan Daerah Tertinggal, dan Transmigrasi (Kemendesa PDTT) bertugas mengawal prioritas penggunaan dana desaagar sesuai dengan Peraturan Menteri yang telah ditetapkan. Berdasarkan Peraturan Menteri Desa, Pembangunan Daerah Tertinggal, dan Transmigrasi Nomor 21 Tahun 2015 tentang Penetapan Prioritas Penggunaan Dana Desa, dana desa di tahun 2016 ini digunakan untuk membiayai pelaksanaan program dan kegiatan berskala lokal desa bidang Pembangunan Desa dan Pemberdayaan Masyarakat Desa. ${ }^{1}$

Seberapa berat masalah kemiskinan ini membebani dunia? Angka-angka statistik berikut memberikan gambaran beratnya dunia memikul beban masalah.

"Pada akhir abad 20 kurang lebih sebanyak 2,8 milyar penduduk penduduk yang hidup dengan 


\begin{tabular}{|c|c|c|c|r|}
\hline SHARE: SOCIAL WORK JURNAL & VOLUME: 6 & NOMOR: 2 & HALAMAN: $154-272$ & $\begin{array}{r}\text { ISSN:2339-0042 }(p) \\
\text { ISSN: } 2528-1577(e)\end{array}$ \\
\hline
\end{tabular}

penghasilan di bawah $\$ 2$ per hari atau 1,2 milyar pend $\$ 1,25$ per hari. World Bank sendiri memperkirakan pada tahun 2005 penduduk miskin ini sebesar 1,3 milyar yang 95\% tersebar di 119 negara sedang berkembang. Melalui program dalam rangka mencapai target MDG's jumlah penduduk miskin ini berkurang menjadi 900 juta pada tahun 2010 . Jika target MDG's tercapai maka jumlah penduduk dunia akan menjadi 600 juta pada tahun 2015" (terjemahan)

http://www.onedayswages.org/about /what-extreme-global-poverty

Angka di atas jelas menunjukkan betapa masih sangat besarnya penduduk dunia ini yang masih hidup dalam kemiskinan.
Bagi Indonesia sendiri kemiskinan juga masih menjadi masalah serius. Meskipun secara statistik jumlah penduduk miskin di Indonesia menunjukkan kecenderungan menurun, kecuali pada tahun 2006. namun secara absolute jumlah penduduk miskin di Indonesia masih sangat besar. Pada tahun 2000 jumlah penduduk miskin di Indonesia mencapai 38,74 juta jiwa. Jumlah ini terus menurun hingga pada tahun 2006 penduduk miskin di Indonesia naik menjadi 39,3 juta.

Gambar 1. Jumlah Penduduk Miskin Indonesia Tahun 1970-2013 (Juta)

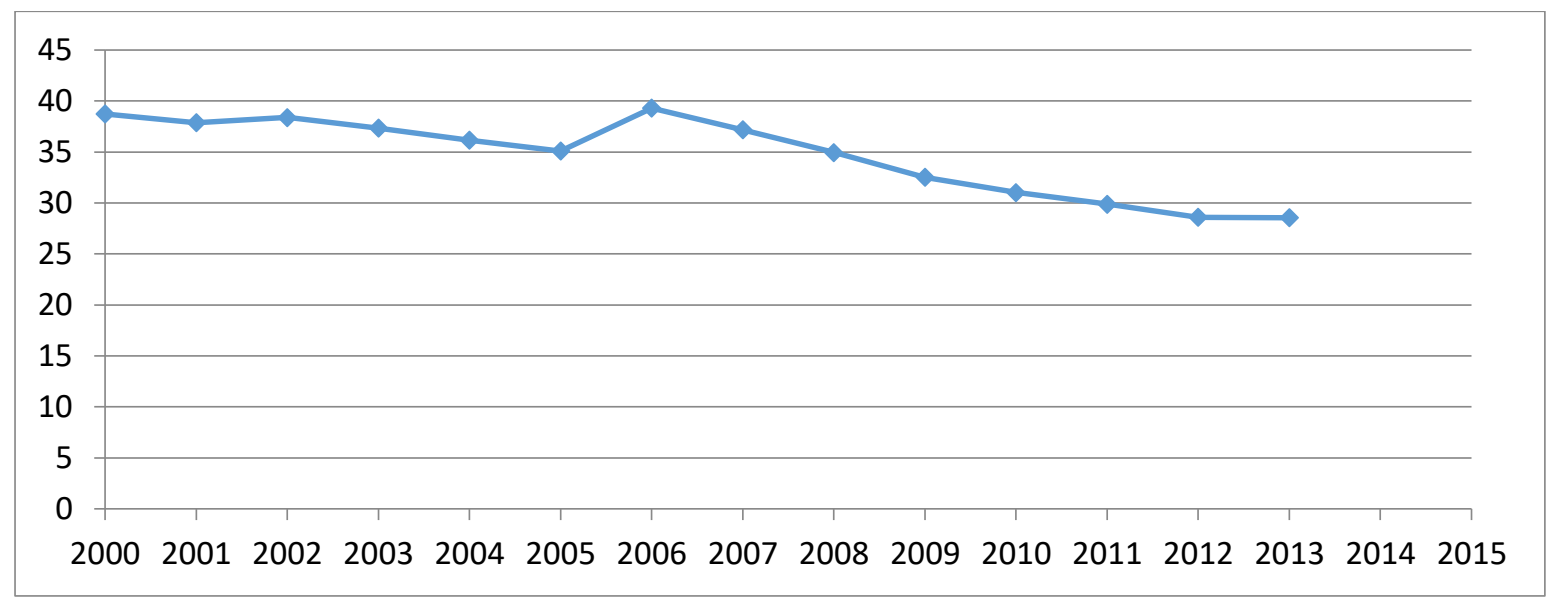

Sumber : BPS, 2015 (diolah)

Pada tahun 2000 jumlah penduduk miskin di Indonesia sebesar 38,74 juta jiwa. Meskipun jumlah penduduk miskin menunjukkan kecenderungan menurun, namun hingga tahun 2013 secara absolut jumlah penduduk miskin di Indonesia masih sangat besar (28,55 juta jiwa) (Gambar 1.). Pada gambar ini terlihat bahwa pada tahun 2006 jumlah penduduk miskin sempat naik hingga 
mencapai 39,3 juta jiwa, kemudian kembali menunjukkan kecenderungan menurun. Kecenderungan kembali menurun pada tahuntahun berikutnya.

Dari grafik di atas terlihat bahwa jumlah penduduk miskin di Indonesia cenderung menurun. Penurunan ini jelas tidak lepas dari berbagai upaya yang telah dilakukan pemerintah untuk menanggulangi kemiskinan. Meskipun demikian, pada tahun 2005-2006 jumlah penduduk miskin sempat mengalami kenaikan. Kenaikan jumlah penduduk miskin pada tahun itu diduga erat kaitannya dengan penurunan subsidi BBM, yang berimbas pada kenaikan harga berbagai komoditas. Di sisi lain daya beli masyarakat justru mengalami penurunan. Situasi ini berimbas pada jumlah penduduk miskin.

Angka statistik memang dapat menggambarkan berat ringannya masalah kemiskinan ini. namun di balik angka statistik ini kemiskinan pada dasarnya mengindikasikan adanya permasalahan yang lebih mendasar. Kemiskinan mengindikasikan adanya ketidakmampuan orang untuk memenuhi kebutuhan-kebutuhan dasar yang pada akhirnya membawa dampak ke berbagai permasalahan. Kemiskinan akan mewariskan generasi yang kekurangan gizi, rentan terhadap penyakit, serta tidak mampu menikmati pendidikan. Pada akhirnya kemiskinan akan mewariskan generasi yang menjadi penyandang masalah sosial, bahkan menjadi sumber masalah sosial. Itulah sebabnya kemiskinan pada akhirnya akan menjadi beban negara dan masyarakat hingga saat ini. Itu pulalah sebabnya kajian terhadap masalah kemiskinan masih sangat aktual untuk dilakukan. Kajian-kajian tentang kemiskinan masih sangat signifikan untuk dilakukan. Kajian dalam tesis inipun terkait dengan kemiskinan.

Kemiskinan adalah persoalan kemanusiaan. Dari dimensi ini adanya kemiskinan membawa konsekuensi adanya tanggung jawab moral bagi setiap orang untuk memperhatikan kehidupan orang yang hidup dalam kemiskinan. Kemiskinan adalah juga merupakan pelanggaran terhadap Hak-Hak Asasi Manusia. “...human rights become a constitutive element of development and human rights violations become both a cause and symptom of poverty" (Tammie O'Nei, 2006,p-7). Hak-hak asasi manusia yang melekat pada diri orang manusia tidak dapat dikurangi, apalagi dicabut. ${ }^{2}$ Dari perspektif ini masalah kemiskinan tidak cukup hanya dilihat dari angka-angka statistik saja. Besar kecilnya masalah kemiskinan tidak dapat hanya dilihat dari persoalan angka statistik. Sekecil apapun angka statistk, di dalamnya terdapat persoalan manusia yang terancam 


\begin{tabular}{|l|l|l|l|l|}
\hline SHARE: SOCIAL WORK JURNAL & VOLUME: 6 & NOMOR: 2 & HALAMAN: $154-272$ & $\begin{array}{r}\text { ISSN:2339-0042 (p) } \\
\text { ISSN: } 2528-1577(e)\end{array}$ \\
\hline
\end{tabular}

hidupnya. Ada manusia yang hak-hak asasinya dilanggar. Jika kemiskinan itu terjadi dalam keluarga, disitu ada anak-anak yang mungkin akan menghadapi masalah sampai tahap kelaparan, kekurangan gizi, hingga kesehatannya bahkan jiwanya terancam. Disitu ada anak-anak yang tidak mampu menikmati pendidikan, yang sebetulnya merupakan haknya. Disitu pula ada pelanggaran hak-hak asasi manusia jika orang-orang di sekitarnya, masyarakatnya, apalagi jika negara membiarkan itu semua terjadi. Dari perspektif hak asasi manusia, adanya kemiskinan adalah tanggung jawab lingkungan, baik dari dalam hal penyebab maupun solusinya. Oleh karena itulah berbagai kajian maupun upaya penanggulangan kemiskinan tidak hanya masih aktual, tetapi juga masih sangat dibutuhkan.

\section{Dari MDGs ke Sustainable Development Goals (SDGs)}

Konsep SDGs itu sendiri lahir pada kegiatan Koferensi mengenai Pembangunan Berkelanjutan yang dilaksanakan oleh PBB di Rio de Jainero tahun 2012. Tujuan yang ingin dihasilkan dalam pertemuan tersebut adalah memperoleh tujuan bersama yang universal yang mampu memelihara keseimbangan tiga dimensi pembangunan berkelanjutan: lingkungan, sosial dan ekonomi.

Dalam menjaga keseimbangan tiga dimensi pembangunan tersebut, maka SDGs memiliki 5 pondasi utama yaitu manusia, planet, kesejahteraan, perdamaian, dan kemitraan yang ingin mencapai tiga tujuan mulia di tahun 2030 berupa mengakhiri kemiskinan, mencapai kesetaraan dan mengatasi perubahan iklim. Kemiskinan masih menjadi isu penting dan utama, selain dua capaian lainnya. Untuk mencapai tiga tujuan mulia tersebut, disusunlah 17 Tujuan Global berikut ini.

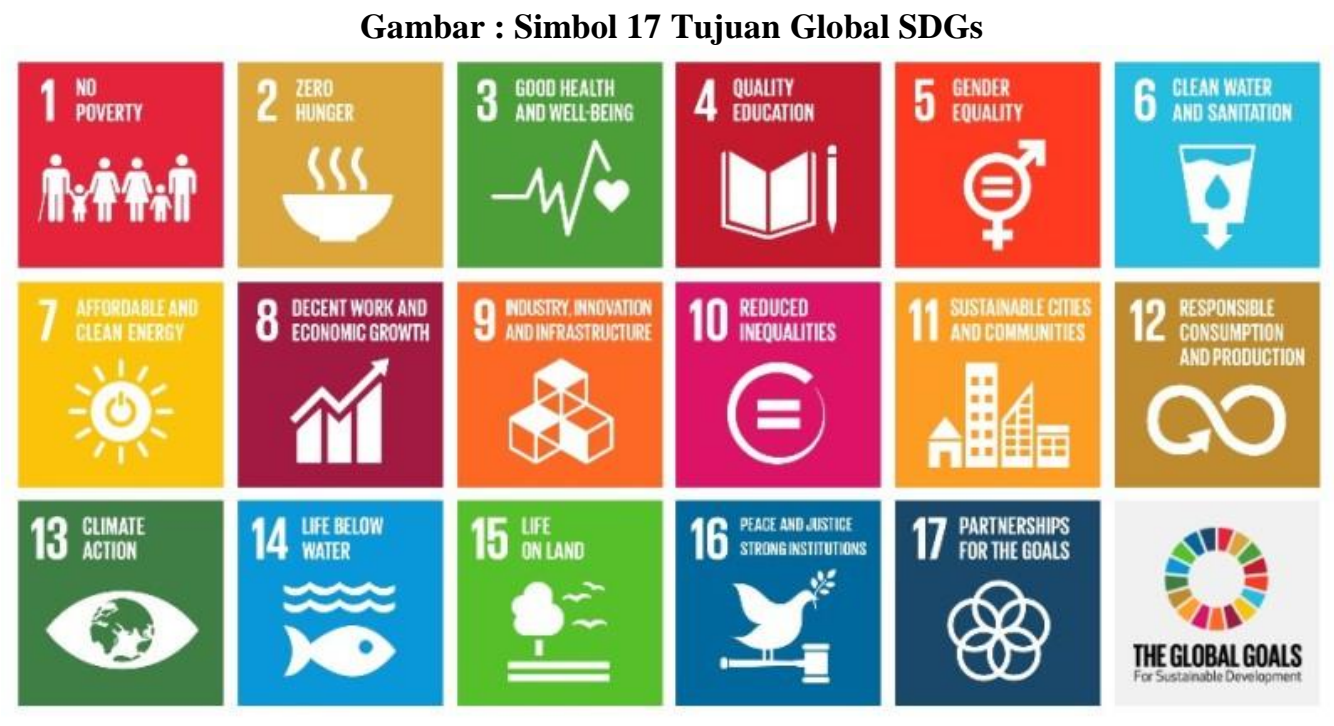


Ke-17 (tujuh belas) Tujuan Global (Global

Goals) dari SDGs tesebut yaitu:

1) Tanpa Kemiskinan. Tidak ada kemiskinan dalam bentuk apapun di seluruh penjuru dunia.

2) Tanpa Kelaparan. Tidak ada lagi kelaparan, mencapai ketahanan pangan, perbaikan nutrisi, serta mendorong budidaya pertanian yang berkelanjutan.

3) Kesehatan yang Baik dan Kesejahteraan. Menjamin kehidupan yang sehat serta mendorong kesejahteraan hidup untuk seluruh masyarakat di segala umur.

4) Pendidikan Berkualitas. Menjamin pemerataan pendidikan yang berkualitas dan meningkatkan kesempatan belajar untuk semua orang, menjamin pendidikan yang inklusif dan berkeadilan serta mendorong kesempatan belajar seumur hidup bagi semua orang.

5) Kesetaraan Gender. Mencapai kesetaraan gender dan memberdayakan kaum ibu dan perempuan.

6) Air Bersih dan Sanitasi. Menjamin ketersediaan air bersih dan sanitasi yang berkelanjutan untuk semua orang.

7) Energi Bersih dan Terjangkau. Menjamin akses terhadap sumber energi yang terjangkau, terpercaya, berkelanjutan dan modern untuk semua orang.

8) Pertumbuhan Ekonomi dan Pekerjaan yang Layak. Mendukung perkembangan ekonomi yang berkelanjutan dan inklusif, lapangan kerja yang penuh dan produktif, serta pekerjaan yang layak untuk semua orang.

9) Industri, Inovasi dan Infrastruktur. Membangun infrastruktur yang berkualitas, mendorong peningkatan industri yang inklusif dan berkelanjutan serta mendorong inovasi.

10) Mengurangi Kesenjangan. Mengurangi ketidaksetaraan baik di dalam sebuah negara maupun di antara negara-negara di dunia.

11) Keberlanjutan Kota dan Komunitas. Membangun kota-kota serta pemukiman yang inklusif, berkualitas, aman, berketahanan dan bekelanjutan.

12) Konsumsi dan Produksi Bertanggung Jawab. Menjamin keberlangsungan konsumsi dan pola produksi.

13) Aksi Terhadap Iklim. Bertindak cepat untuk memerangi perubahan iklim dan dampaknya.

14) Kehidupan Bawah Laut. Melestarikan dan menjaga keberlangsungan laut dan kehidupan sumber daya laut untuk perkembangan pembangunan yang berkelanjutan. 


\begin{tabular}{|c|c|c|c|r|}
\hline SHARE: SOCIAL WORK JURNAL & VOLUME: 6 & NOMOR: 2 & HALAMAN: $154-272$ & $\begin{array}{r}\text { ISSN:2339-0042 }(p) \\
\text { ISSN: 2528-1577 }(e)\end{array}$ \\
\hline
\end{tabular}

15) Kehidupan di Darat. Melindungi, mengembalikan, dan meningkatkan keberlangsungan pemakaian ekosistem darat, mengelola hutan secara berkelanjutan, mengurangi tanah tandus serta tukar guling tanah, memerangi penggurunan, menghentikan dan memulihkan degradasi tanah, serta menghentikan kerugian keanekaragaman hayati.

16) Institusi Peradilan yang Kuat dan Kedamaian. Meningkatkan perdamaian termasuk masyarakat untuk pembangunan berkelanjutan, menyediakan akses untuk keadilan bagi semua orang termasuk lembaga dan bertanggung jawab untuk seluruh kalangan, serta membangun institusi yang efektif, akuntabel, dan inklusif di seluruh tingkatan.

17) Kemitraan untuk Mencapai Tujuan. Memperkuat implementasi dan menghidupkan kembali kemitraan global untuk pembangunan yang berkelanjutan.

Menyikapi 17 Tujuan Global tersebut, Presiden Majelis Umum PBB menegaskan bahwa ambisi dari negara-negara anggota PBB tersebut hanya akan tercapai jika dunia telah

\footnotetext{
${ }^{3}$ Markus Sembiring,S.Pi.,M.I.L Penyuluh Perikanan Muda, Dinas Perikanan dan Kelautan Kabupaten Langkat http://www.pusluh.kkp.go.id/
}

damai, aman, serta menghormati hak asasi manusia bukan di dunia di mana investasi dalam persenjataan dan perang lebih besar sehingga menghancurkan sebagian besar sumber daya yang telah menjadi komitmen untuk berinvestasi dalam pembangunan berkelanjutan.

Terdapat 7 (tujuh) alasan mengapa SDGs akan lebih baik dari MDGs, yakni: ${ }^{3}$

1) SDGs lebih global dalam mengkolaborasikan programprogramnya. MDGs sebelumnya dibuat oleh anggota negara The Organization for Economic Cooperation and Developmen (OECD) dan beberapa lembaga internasional. Sementara SDGs dibuat secara detail dengan negosiasi internasional yang juga terdiri dari negara berpendapatan menengah dan rendah.

2) Sekarang, sektor swasta juga akan memiliki peran yang sama, bahkan lebih besar.

3) MDGs tidak memiliki standar dasar hak asasi manusia (HAM). MDGs dianggap gagal untuk memberikan prioritas keadilan yang merata dalam bentuk-bentuk diskriminasi dan pelanggaran HAM, yang akhirnya berujung kepada masih banyaknya 
orang yang terjebak dalam kemiskinan.

Sementara SDGs dinilai sudah didukung dengan dasar-dasar dan prinsip-prinsip HAM yang lebih baik.

4) SDGs adalah program inklusif. Tujuh target SDG sangat eksplisit tertuju kepada orang dengan kecacatan, dan tambahan enam target untuk situasi darurat, ada juga tujuh target bersifat universal dan dua target ditujukan untuk antidiskriminasi.

5) Indikator-indikator yang digunakan memberikan kesempatan untuk keterlibatan masyarakat sipil.

6) PBB dinilai bisa menginspirasi negaranegara di dunia dengan SDGs.

7) Conference of the Parties 21 (COP21) di Paris melahirkan perjanjian global perubahan iklim sebagai kerangka transisi menuju ekonomi dan masyarakat rendah karbon dan memiliki ketahanan terhadap perubahan iklim adalah salah satu kesempatan untuk maju.

\section{Penutup}

Pekerjaan Sosial mempunyai relevansi yang sangat kuat dengan masalah kemiskinan. Sudah berabad-abad profesi ini bergelut dan terlibat dalam penanganan kemiskinan. Secara historis profesi Pekerjaan Sosial boleh dikatakan lahir dari masalah kemiskinan. Profesi ini bahkan menempatkan masalah kemiskinan sebagai bidang utama yang ditangani Pekerjaan Sosial. Jika sangat menjunjung tinggi prinsip-prinsip Hak-Hak Azasi Manusia, Pekerjaan Sosial harus berada di garis depan dalam upaya mengatasi kemiskinan. MDGs yang kemudian bergeser ke SDGs merupakan tujuan bersama yang memerlukan pengalawan bersama baik vertical maupun horizontal.

\section{DAFTAR PUSTAKA}

Akhmadi, 2006, Studi Keluar dari Kemiskinan Kasus di Komunitas RW 4, Dusun Kiuteta, Desa Noelbaki, Kecamatan Kupang Tengah, Kabupaten Kupang, Nusa Tenggara Timur, Lembaga Penelitian SMERU, Jakarta.

Causes \& Effects of Poverty On Society, Children \& Violence poverties.org Research for social \& economic development - See more at:

http://www.poverties.org/effects-ofpoverty.html\#sthash.lFOQKxdi.dpuf Published March 2011 - Updated May 2013:8)

Francis, Tazoacha, 2001, The Causes and Impact of Poverty on Sustainable Development in Africa, A Paper Presented at The Conference "Poverty and Sustainable Development “ Held In Bordeaux, France from November 22-23, 2001 
Graeme Stuart, 2012, What is Strengths Perspective, Sustaining Cummunity

Maia Green, Representing poverty and attacking representations: some anthropological perspectives on poverty in development

Maryann Roebuck,2007, The Strength-Based Approach : Philosophy and Principles for Practice,

Raharjo, ST. 2016. Asesmen dan Wawancara dalam Praktik Pekerjaan Sosial dan Kesejahteraan Sosial. Unpad Press: Bandung

Schiller, Bradle R. 1998, The Economics of Poverty sn Discrimination, $7^{\text {th }}$ edition,Prentice Hall. New Jersey.

The World Bank , 2001, World Development Report 2000/2001, Attacking, (C) 2001 The International Bank for Reconstruction and Development / The World Bank, 1818 H Street, N.W., Washington, D.C. 20433, U.S.A.

BPS, 2010, Profil Kemiskinan di Indonesia Maret 2010, Berita Resmi Statistik, BPS, No.45/07/Th. XIII, 1 Juli 2010, Jakarta.

-----, 2009, Profil Kemiskinan di Indonesia Maret 2009, Berita Resmi Statistik BPS, No. 43/07/Th. XII, 1 Juli 2009 , Jakarta.

United Nations, 1995, World Summit for Social Development, Copenhagen, Denmark, www.un.org/documents/ga/conf166 laconf166-9.htm, diunduh 25agustus 2015

2013, The Millennium

Development Goals Report. New York,

Laura Ellis and Elaine Weekse, 2011, Why Use a Strengths-Dede Approach Instead of a Deficit-Based Approach?, www.mtroyal.ca/cs/groups/public/.../ pdf_why_strengths_not_deficit.pdf
Maia Green, Representing poverty and attacking representations: some anthropological perspectives on poverty in development,

Natalie Scerra, 2011, Strength-Based Practice, The Evidence, a Discussion Paper, Research-Paper July 2011, Uniting Care Children, Young People, and Families, New South Wales)

Office of the United Nations High Commissioner for Human Rights Principles and Guidelines for Human Rights Approach to Poverty Reduction Strategies [online] Available at, http://www.ohchr.org/Documents/Pu blications/ PovertyStrategiesen. pdf $>$ [Accessed 10 January 2012] (Poverty - Social Work Policy Institute http://www.socialworkpolicy.org research/poverty.html 2feb2013)

Tammie O'Nei, 2006, Human Rights and Poverty Reduction: Realities, Controversies and Strategies, An ODI Meeting Series (editorial), Overseas Development Institute 2006.

Office of the United Nations High Commissioner for Human Rights Principles and Guidelines for Human Rights Approach to Poverty Reduction Strategies, 1991, What Poverty is, http://www.thl.fi/thlclient/pdfs/b8f78a80-ac1d-49ff-a50af6e14fd80dde diunduh 15 januari2015

https://sites.google.com/site/solutionfocuseda pproach/5-study-materials/2strengths--based-approachdefinition-history-philisophyprinciples-and-practice 